\title{
Calcineurin Aa Contributes to IgE-Dependent Mast-Cell Mediator Secretion in Allergic Inflammation
}

\author{
Edwin Leong $^{a}$ Zheng Pang ${ }^{a}$ Andrew W. Stadnyk ${ }^{a, b, c}$ Tong-Jun Lin ${ }^{a, b, c}$ \\ ${ }^{a}$ Department of Pathology, Dalhousie University, Halifax, NS, Canada; ${ }^{b}$ Department of Pediatrics, \\ Isaac Walton Killam Health Centre, Halifax, NS, Canada; 'Department of Microbiology \& Immunology, \\ Dalhousie University, Halifax, NS, Canada
}

\section{Keywords}

Allergy · Allergic inflammation · Calcineurin · Degranulation · Vascular permeability

\begin{abstract}
Mast cells (MCs) are key mediators of allergic inflammation through the activation of cross-linked immunoglobulin $\mathrm{E}$ $(\mathrm{lgE})$ bound to the high-affinity $\mathrm{lg} \mathrm{E}$ receptor ( $\mathrm{Fc} \in \mathrm{RI}$ ) on the cell surface, leading to the release of biologically potent mediators, either from preformed granules or newly synthesized. Pharmacological inhibitors have been developed to target a key signaling protein phosphatase in this pathway, calcineurin, yet there is a lack of genetic and definitive evidence for the various isoforms of calcineurin subunits in FceRl-mediated responses. In this study, we hypothesized that deficiency in the calcineurin Aa isoform will result in a decreased allergic immune response by the MCs. In a model of passive cutaneous anaphylaxis, there was a reduction in vascular permeability in MC-deficient mouse tissues reconstituted with calcineurin subunit $\mathrm{A}(\mathrm{CnAa})$ gene-knockout $\left(\mathrm{CnAa}^{-/-}\right) \mathrm{MCs}$, and in vitro experiments identified a significant reduction in release of preformed mediators from granules. Furthermore, released levels of de novo synthe-
\end{abstract}

karger@karger.com www.karger.com/jin

Karger!"
(C) 2021 The Author(s)

Published by S. Karger AG, Basel

This is an Open Access article licensed under the Creative Commons Attribution-NonCommercial-4.0 International License (CC BY-NC) (http://www.karger.com/Services/OpenAccessLicense), applicable to the online version of the article only. Usage and distribution for commercial purposes requires written permission. sized cytokines were reduced upon $\mathrm{Fc \in RI}$ activation of $\mathrm{CnAa}{ }^{-/-} \mathrm{MCs}$ in vitro. Characterizing the mechanisms associated with this deficit response, we found a significant impairment of nuclear factor of kappa light polypeptide gene enhancer in B cell phosphorylation and impaired nuclear factor kappa-light-chain-enhancer of activated B-cell inhibitor alpha (NF-KB) activation. Thus, we concluded that $\mathrm{CnAa}$ contributes to the release of preformed mediators and newly synthesized mediators from Fc $\in \mathrm{RI}-$ mediated activation of $M C s$, and this regulation includes NF-KB signaling.

C 2021 The Author(s).
Published by S. Karger AG, Basel

\section{Introduction}

Allergic inflammation, or allergy, is an excessive and inappropriate immune response against specific though otherwise harmless allergens that the immune system had been previously sensitized to [1]. The inflammation in the allergic response is a result of a coordination of signaling cascades of various immune cell types and secretory mechanisms [2]. One immune cell type identified as the conductor in allergy and ensuing pathology is the mast cell (MC). Activation of the MC by an allergen elicits the 
release of a plethora of inflammatory products that have effects manifesting in the overall allergic inflammatory response [3-5]. As MCs are tissue-resident sentinel cells populating sites of host-external environment interfaces, they are primed by specific immunoglobulin E (IgE) following the initial allergen exposure and subsequently coordinate the response through the release of potent mediators on a challenge exposure. Thus, it is crucial to understand the mechanisms underlying MC activation by the allergen.

$\mathrm{MC}$-allergen interactions are mediated by $\operatorname{IgE}$ bound to the tetrameric high-affinity IgE receptor, FceRI. FceRI comprises 3 subunits, an $\alpha$-chain that binds to $\operatorname{IgE}$, a $\beta$-chain that amplifies signaling, and $2 \gamma$-chains that are responsible for signal transduction through immunoreceptor tyrosine-based activation motifs. Aggregation and cross-linking of antigen (Ag)-bound IgE on FceRI result in internalization of the complex and initiation of the FceRI-mediated signaling pathway. The FceRI-mediated signaling pathway, recently reviewed by others, is highly complex $[6,7]$. Briefly, multiple signaling pathways are activated including nuclear factor of activated T cells, mitogen-activated protein kinases (MAPKs), and nuclear factor kappa-light-chain-enhancer of activated B cells (NF- $\kappa B)$ [8]. The FceRI signaling cascade essentially results in 2 main events: (1) degranulation of preformed mediators and (2) de novo production and secretion of lipid mediators, cytokines, and chemokines.

Calcineurin is a serine-threonine protein phosphatase conserved in all eukaryotes with important functions in multiple cell types and signaling pathways [9]. Calcineurin is composed of a catalytic $\mathrm{A}(\mathrm{CnA})$ and regulatory $\mathrm{B}$ $(\mathrm{CnB})$ subunit, and each subunit contains specific domains that promote the activation of calcineurin in a calcium-dependent manner. The catalytic subunit consists of 3 isoforms - $\alpha(C n A \alpha), \beta(C n A \beta)$, and $\gamma(C n A \gamma)$. $C n A \alpha$ and $C n A \beta$ are ubiquitously expressed, while $C n A \gamma$ is found in limited tissues [10]. Binding of calcium to $\mathrm{CnB}$ and calmodulin promotes conformational changes to calcineurin and the removal of an auto-inhibitory domain on $\mathrm{CnA}$, allowing interactions with substrates [11-13]. The interaction between calcineurin and a variety of substrates regulates many physiological functions, ranging from cell cycle and apoptosis to immune responses [14, 15]. We reported that the regulator of calcineurin (Rcan) 1 negatively regulates FceRI-mediated allergic inflammation through suppression of calcineurin, implicating calcineurin in the FceRI response [16].

Dysregulation of interactions between calcineurin and transcription factor substrates has provided the impetus for research on calcineurin inhibitors as a form of a therapeutic. Calcineurin inhibitors such as cyclosporine A and tacrolimus have been instrumental in successful organ transplantation $[17,18]$. However, calcineurin inhibitors also result in nephrotoxicity and hypertension [18, 19], which indicates that further research on the mechanisms is necessary. The safety of calcineurin inhibitors in allergies has been acknowledged, and long-term studies are in progress [20-22]. Since most of our knowledge on calcineurin and allergies is based on the use of inhibitors, we are still lacking genetic and definitive evidence of the mechanistic roles that calcineurin plays in the FceRImediated immune response to an allergen - specifically the contributions of the different isoforms.

There has been limited research implicating $C n A \alpha$ in physiological settings. The homozygous $\mathrm{CnAa}$ gene deficiency results in early lethality in mouse pups, a limitation to studying gene knockout mice [23]. One group overcame this obstacle by dietary intervention to show $C n A \alpha$ deficiency impaired in vivo $\mathrm{T}$-cell responses to the antigen [24]. Otherwise, there is a paucity of literature or research on this calcineurin isoform in MCs and the FceRImediated immune response despite the use of calcineurin inhibitors to treat allergy. Thus, it is important to delineate and understand the mechanisms in which $C n A \alpha$ contributes to FceRI-mediated allergic inflammation so that improvements can be made in therapeutic approaches concerning calcineurin. In this study, using cells cultured and differentiated from homozygous knockout pups' livers, we identified $\mathrm{CnAa}$ as a contributor to the early phase of FceRI-mediated MC-specific allergic inflammation events.

\section{Materials and Methods}

\section{Animals}

$\mathrm{CnA} \alpha^{+/-}$mice were generously provided by Dr. Jennifer Gooch (Emory University, Atlanta, GA, USA). MC-deficient $\mathrm{Kit}^{W-s h}$ mice were purchased from the Jackson Laboratory, Bar Harbor, ME, USA (B6Cg-kit W-sh/HNiHJacBsmJ NistltF4). Mice colonies were bred and housed in the Izaak Walton Killam Health Centre Animal Care Facility where food and water were provided ad libitum prior to and during experimentation. Protocols were approved by the University Committee on Laboratory Animals, Dalhousie University, Canada, in accordance with the guidelines of the Canadian Council of Animal Care.

\section{Antibodies and Reagents}

The anti-calcineurin Aa antibody was purchased from Millipore (Billerica, MA, USA). Antibodies to phospho-p38 mitogenactivated protein kinase (MAPK) (Thr 180/Tyr 182), phosphoJNK (Thr 183/Tyr 185), JNK, phospho-ERK1/2 (Thr202/Tyr204), 
ERK, phospho-nuclear factor of kappa light polypeptide gene en-

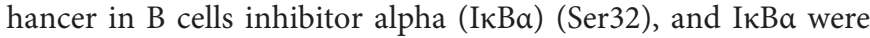
purchased from Cell Signaling Technology (Beverly, MA, USA). Antibodies to p38, actin, and HRP-linked secondary antibodies were purchased from Santa Cruz Biotechnology (Dallas, TX, USA). Fluorescein isothiocyanate (FITC)-conjugated rat antimouse IgE (clone: R35-72) and isotype control FITC-rat IgG1 (clone: R3-34) were purchased from BD Biosciences (San Jose, CA, USA). FITC-conjugated rat anti-mouse CD117 (clone: 2B8) mAb and isotype control FITC-rat IgG2b (eB149/10H5) were purchased from eBioscience (Thermo Fisher Scientific, Waltham, MA, USA). Trinitrophenyl (TNP)-bovine serum albumin (BSA) and dinitrophenyl (DNP)-BSA were purchased from Biosearch Technologies (Novato, CA, USA). Anti-DNP IgE mAb was purchased from Sigma-Aldrich (St. Louis, MO, USA). Standard (DuoSet) enzyme-linked immunoSorbent assay (ELISA) kits were purchased from R\&D Systems (Minneapolis, MN, USA).

\section{Culture and Activation}

Mouse liver-derived MCs (LMCs) were obtained by culturing liver cells from neonatal mice from $C n A \alpha^{+/-}$parents. Briefly, liver tissue was removed to a laminar flow hood and ground to produce a cell suspension in Roswell Park Memorial Institute (RPMI) 1640 medium, passed through a $40-\mu \mathrm{m}$ cell strainer, then centrifuged at $500 \mathrm{~g}$ for $5 \mathrm{~min}$ at $4^{\circ} \mathrm{C}$ and finally resuspended at a density of $0.5 \times$ $10^{6}$ cells $/ \mathrm{mL}$ in complete medium. Complete MC media consists of RPMI 1640 with L-glutamine, 10\% heat-inactivated fetal bovine serum (Gibco, Thermo Fisher Scientific), 10\% WEHI-3B conditioned medium, $1 \%$ penicillin/streptomycin (Gibco, Thermo Fisher Scientific), 50 M 2-mercaptoethanol (Sigma-Aldrich), and 200 $\mathrm{nM}$ prostaglandin $\mathrm{E}_{2}$ (Sigma-Aldrich). Mouse stem-cell factor (mSCF) (Peprotech, Rocky Hill, NJ, USA) was supplemented into each flask at a final concentration of $30 \mathrm{ng} / \mathrm{mL}$. An aliquot of cells isolated from each mouse was taken for genotyping. Nonadherent cells were resuspended twice a week in fresh complete media supplemented with fresh $\mathrm{mSCF}$ and transferred to a new flask once per week. MCs were confirmed using toluidine blue staining of fixed cytocentrifuged preparations. After 4-6 weeks in culture, the purity of liver-derived cultured MCs was $>95 \%$. For activation, LMCs were passively sensitized overnight with IgE (from TIB-141 cells; American Type Culture Collection, Manassas, VA, USA) and washed twice, followed by activation with $10 \mathrm{ng} / \mathrm{mL}$ TNP-BSA (Biosearch Technologies).

\section{Flow Cytometry, Degranulation, and Calcium Mobilization}

Samples from monocultures were stained directly using either FITC-CD117, FITC-rat IgG2b (FITC-CD117 isotype control), FITC-IgE, or FITC-rat IgG1 (FITC-IgE isotype control) antibodies and the signal acquired using flow cytometry (imaged using a FACSCalibur), using concentrations following the manufacturers' instructions. CD117 was detected directly using FITC-conjugated antibody. For detection of FceRI, LMCs were passively sensitized with IgE overnight, and the bound IgE detected with anti-IgE antibody. Data analysis was done using FlowJo V10 software (BD Biosciences). For degranulation assays, sensitized LMCs were activated through stimulation with $10 \mathrm{ng} / \mathrm{mL}$ TNP-BSA for $20 \mathrm{~min}$. Degranulation was determined by measuring secreted and total $\beta$-hexosaminidase. The result is reported as a secreted product as a percent of the total $\beta$-hexosaminidase. Intracellular calcium mobilization was determined as previously described [25].

\section{ELISA and Western Blotting}

IgE-sensitized LMCs were either unstimulated or stimulated with $10 \mathrm{ng} / \mathrm{mL}$ TNP-BSA for $30 \mathrm{~min}, 1,3,6$, or $24 \mathrm{~h}$, and supernatants collected for ELISA. Antibodies and standards (DuoSet) were from R\&D Systems, and ELISAs were conducted according to the manufacturer's protocol. Control and activated LMCs were lysed in prepared lysis buffer (RIPA) supplemented with HALT TM protease and phosphatase inhibitor cocktail (Thermo Fisher). Protein concentrations were determined in cleared lysates, and $30 \mu \mathrm{g}$ used for electrophoresis in 10\% SDS-polyacrylamide gels. Gels were transferred to polyvinylidene difluoride membranes, blocked with $5 \%$ nonfat milk, probed with primary and corresponding secondary antibodies, and detected using an ECL detection system (Western Lightning Plus-ECL; PerkinElmer, Waltham, MA, USA) on a BioMax film (Kodak; Sigma-Aldrich). Blots were scanned and quantified using ImageJ software v1.50.

\section{Real-Time Quantitative Polymerase Chain Reaction}

LMCs were either unstimulated or stimulated with $10 \mathrm{ng} / \mathrm{mL}$ TNP-BSA, and cell pellets lysed with Trizol (Invitrogen, Thermo Fisher Scientific) for RNA isolation following the manufacturer's instructions. cDNA synthesis was conducted using $1 \mu \mathrm{g}$ of RNA and RNA to cDNA EcoDry Premix (Takara Bio USA, Mountain View, CA, USA) following the manufacturer's protocol and thermocycler settings. Samples were prepared for real-time quantitative polymerase chain reaction (RT-qPCR) using the following master mix components: $10 \mu \mathrm{L}$ molecular grade $\mathrm{H}_{2} \mathrm{O}$ (Invitrogen, Thermo Fisher Scientific), $4 \mu \mathrm{L}$ SsoAdvanced Universal SYBR Green Supermix (Bio-Rad Laboratories), $2 \mu \mathrm{L} 10 \mu \mathrm{M}$ forward primer, $2 \mu \mathrm{L} 10 \mu \mathrm{M}$ reverse primer, and $2 \mu \mathrm{L}$ cDNA. Gene expression was measured using a CFX Connect Real-time System (Bio-Rad Laboratories), and data processed on Bio-Rad CFX Manager 3.1 software. Melt curve analyses were run to determine target specificity. Gene expression levels were normalized to hypoxanthine guanine phosphoribosyltransferase mRNA and analyzed using the $\Delta \Delta \mathrm{Ct}$ method. Primer sequences are reported in Table 1.

\section{Electrophoretic Mobility Shift Assay}

LMCs were unstimulated or stimulated with TNP-BSA, and cell pellets used for nuclear protein isolation. Nuclear protein extracts were obtained using a nuclear extract kit (Active Motif, Carlsbad, CA, USA) according to the manufacturer's protocol. Double-stranded oligonucleotide probes were labeled using T4 kinase (Life Technologies, Burlington, ON, USA) in the presence of ${ }^{32} \mathrm{P}$-ATP (PerkinElmer) for $30 \mathrm{~min}$ at $37^{\circ} \mathrm{C}$. Labeled probes were purified on a Sephadex G-25M column (GE Healthcare, Pittsburgh, PA, USA). Nuclear protein $(8 \mu \mathrm{g})$ was added to a $10 \mu \mathrm{L}$ reaction mixture containing binder buffer and supplemented with 1 $\mu \mathrm{g}$ poly-(dI-dC) (GE Healthcare) for $15 \mathrm{~min}$. Labeled and purified probe was added to each reaction mixture and incubated at room temperature for $30 \mathrm{~min}$. Separation by electrophoresis was done on a $6 \%$ polyacrylamide gel in $0.5 \mathrm{X}$ Tris-boric acid-EDTA buffer. Gels were vacuum dried for $2 \mathrm{~h}$ and subjected to autoradiography. The following double-stranded oligonucleotide (Integrated DNA Technologies) was used: NF- $\kappa B$ binding consensus sequence on mouse IL-6 promoter $5^{\prime}$-TTA TCA AAT GTG GGA TTT TCC CAT-3'. Quantification was assessed by densitometric analysis of scanned blots using ImageJ software. 
Table 1. Primer sequences for genes of interest measured using RT-qPCR

\begin{tabular}{lll}
\hline Primer & Predicted size & Primer sequence 5'-3' \\
\hline $\begin{array}{l}\text { TNF forward } \\
\text { TNF reverse }\end{array}$ & $\sim 174 \mathrm{bp}$ & $\begin{array}{l}\text { CAT CTT CTC AAA ATT CGA GTG ACA A } \\
\text { TGG GAG TAG ACA AGG TAC AAC CC }\end{array}$ \\
\hline IL-6 forward & $\sim 77 \mathrm{bp}$ & TAG TCC TTC CTA CCC CAA TTT CC \\
IL-6 reverse & TTG GTC CTT AGC CAC TCC TTC \\
\hline IL-13 forward & $\sim 108 \mathrm{bp}$ & CTG TGT CTC TCC CTC TGA CCC \\
IL-13 reverse & GCC AGG TCC ACA CTC CAT ACC \\
\hline IL-4 forward & $\sim 77 \mathrm{bp}$ & CAT GCA CGG AGA TGG ATG TGC \\
IL-4 reverse & AAG CCC TAC AGA CGA GCT CAC \\
\hline HPRT forward & $\sim 229 \mathrm{bp}$ & CAC AGG ACT AGA ACA CCT GC \\
HPRT reverse & GCT GGT GAA AAG GAC CTC T \\
\hline
\end{tabular}

RT-qPCR, real-time quantitative polymerase chain reaction; HPRT, hypoxanthine guanine phosphoribosyltransferase; TNF, tumor necrosis factor.
Reconstitution of MC-Deficient Kit ${ }^{W-s h}$ Mice

$\mathrm{Kit}^{\mathrm{W} \text {-sh }}$ mice were reconstituted by intradermal injection of LMCs at a density of $25 \times 10^{6}$ cells/mL in $20 \mu \mathrm{L}$ fresh RPMI $1640\left(5 \times 10^{5}\right.$ cells/injection) into the ear pinnae using 31 -gauge insulin needles. $\mathrm{CnA} \alpha^{+/+}$LMCs were injected into the right ear pinna, and $\mathrm{CnA \alpha ^{-/- }}$ LMCs were injected into the left ear pinna. Six weeks later, $\mathrm{Kit}^{\mathrm{W}-\mathrm{sh}}$ mice were used in a model of IgE-mediated passive cutaneous anaphylaxis as described below. Nonreconstituted $\mathrm{Kit}^{\mathrm{W} \text {-sh }}$ littermates were used as controls. All mice used were sex and age-matched.

\section{IgE-Dependent Passive Cutaneous Reaction}

$K i t^{W-s h}$ mice reconstituted for 6 weeks with wild-type MCs in right ears, and $\mathrm{CnA \alpha ^{-/- }}$ MCs in left ears were anaesthetized and sensitized with $20 \mu \mathrm{L}$ of $1 \mathrm{ng} / \mu \mathrm{L}$ anti-DNP IgE mAb (Sigma-Aldrich) using an insulin syringe into the dorsal side of the ear pinnae. Ten microliters of $10 \mathrm{mg} / \mathrm{mL}$ DNP-BSA was mixed with 190 $\mu \mathrm{L} 1 \%$ Evan's Blue dye (Sigma-Aldrich) and left overnight at $4^{\circ} \mathrm{C}$. The following day, DNP-BSA in Evan's Blue dye (working concentration of $500 \mu \mathrm{g} / \mathrm{mL}$ ) was intravenously injected into each sensitized mouse with a 30 -gauge needle through the tail vein. The reaction occurred for $30 \mathrm{~min}$ before mice were sacrificed, and ear tissues harvested into tubes. Ear tissues were cut into pieces and immersed in $2 \mathrm{~mL} \mathrm{~N}, \mathrm{~N}$-dimethyl formamide (Sigma-Aldrich) for $2 \mathrm{~h}$ in an $80^{\circ} \mathrm{C}$ water bath to extract the blue dye. Tubes were centrifuged, and $200 \mu \mathrm{L}$ of supernatant was collected from each to measure absorbance at $620 \mathrm{~nm}$. Only reconstituted mice with successful intradermal injections of LMCs in ear tissues and sensitization were used - if the needle perforates both sides of the ear tissue, there may be possible leakage, and these mice were not used in the analyses. Furthermore, only mice that received successful intravenous tail vein injections on the first attempt were used, to ensure that the same volumes of DNP-BSA in Evan's Blue dye were administered among the reconstituted mice.

\section{Statistical Analyses}

Statistical analyses included 1-way analysis of variance, $t$ tests, and paired $t$ tests as appropriate, and differences were considered significant when $p \leq 0.05$. Data displayed in figures are represented as mean \pm standard error of the mean.

Role of Calcineurin Aa in Allergic Inflammation

\section{Results}

CnA $\alpha$ Wild-Type and Deficient MCs Show Similar Development and Morphology

To determine if $C n A \alpha$ has a role in the development of MCs, $C n A \alpha^{+/+}$and $C n A \alpha^{-/-}$LMC cultures were established from neonatal liver cells in media conditioned with mSCF, IL-3, and $\mathrm{PGE}_{2}$ to promote the maturation and proliferation of liver-derived progenitor cells into MCs. The CnAa gene knockout was confirmed using PCR by the presence of the inserted neomycin cassette used to disrupt a section of the wild-type (WT) gene (Fig. 1a). Characteristics of cultured LMCs, assessed using toluidine blue staining, showed comparable morphology and metachromatic staining for granularity, indicative of similar development in both genotypes of LMCs (Fig. 1b). Furthermore, the kinetics of MC num-

Fig. 1. LMCs from $C n A \alpha$-deficient mice have similar morphology and development compared to WT in vitro. a Representative genotyping results of WT, $C n A \alpha$-deficient (KO), and $C n A \alpha$ heterozygous (HZ) samples with labeled DNA ladder. The predicted sizes of $C n A \alpha$ WT and $C n A \alpha$ mutant (neomycin cassette insertion) are $247 \mathrm{bp}$ and $360 \mathrm{bp}$, respectively. b Representative image using toluidine blue staining of each genotype (original magnification $\times 100)$. c, d Flow cytometric detection of surface molecules of WT (left) and $\mathrm{CnA} \alpha$-deficient LMCs (KO, right) sensitized with antiTNP IgE and then stained with either FITC-conjugated antiCD117 (c) or anti-IgE antibodies (d). Red peaks are isotype controls. e Intracellular calcium flux was compared between FceRImediated activated WT and $C n A \alpha$-deficient LMCs. BP, base pairs; WT, wild-type; LMC, liver-derived mast cells; CnAa, calcineurin subunit A; FITC, fluorescein isothiocyanate; TNP, trinitrophenol; FceRI, high-affinity receptor for immunoglobulin E; IgE, immunoglobulin E.

(For figure see next page.)

J Innate Immun 2022;14:320-334 

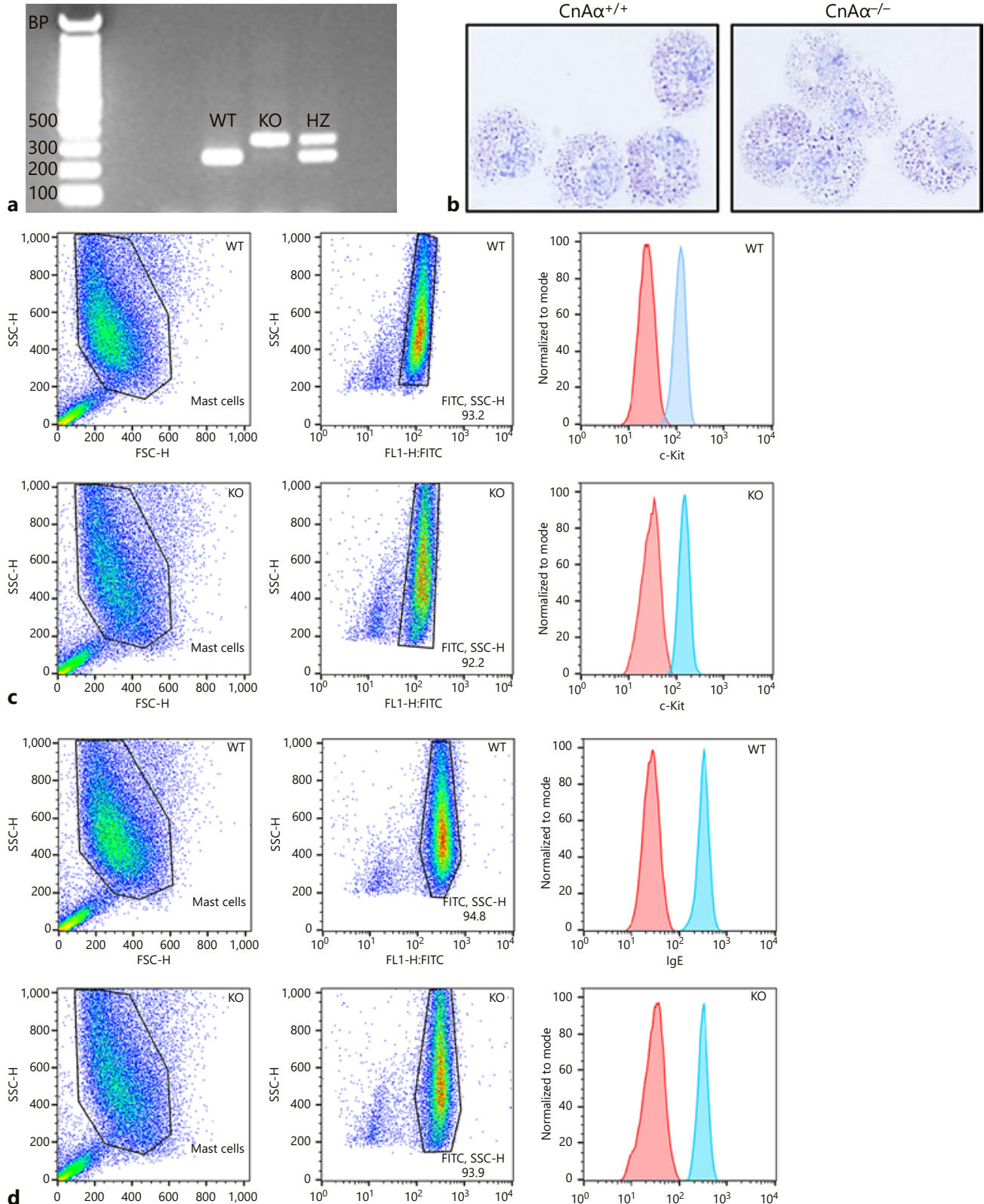

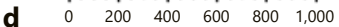

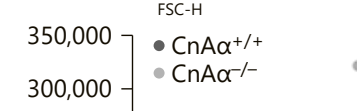
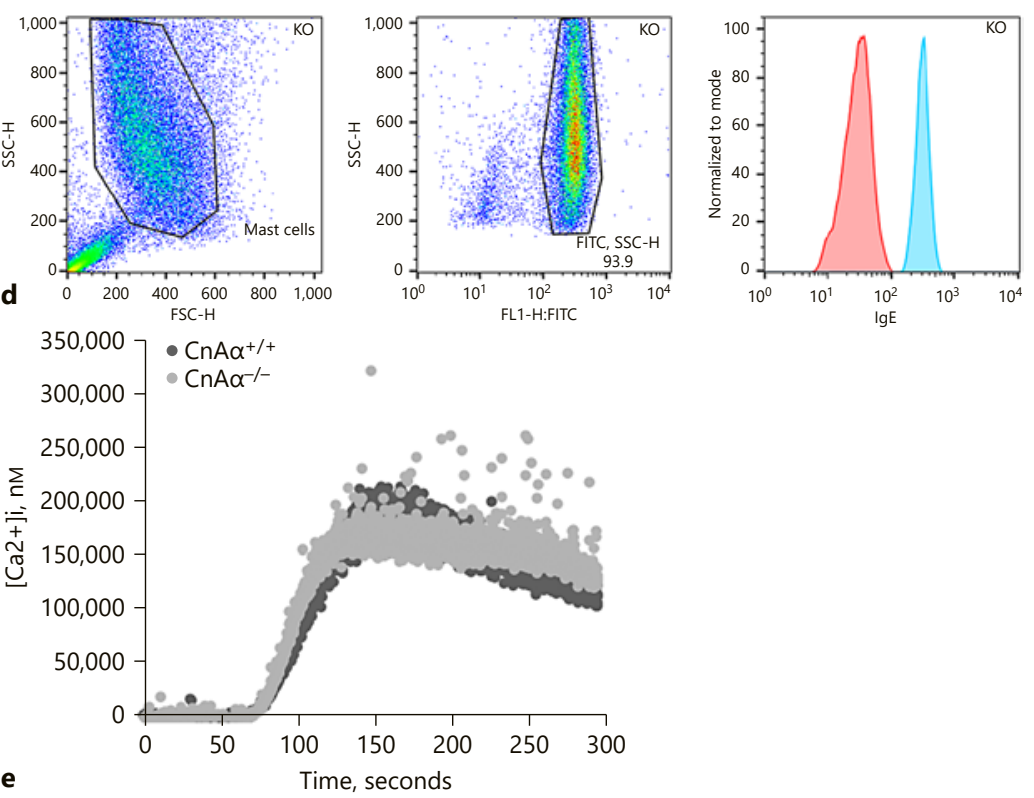

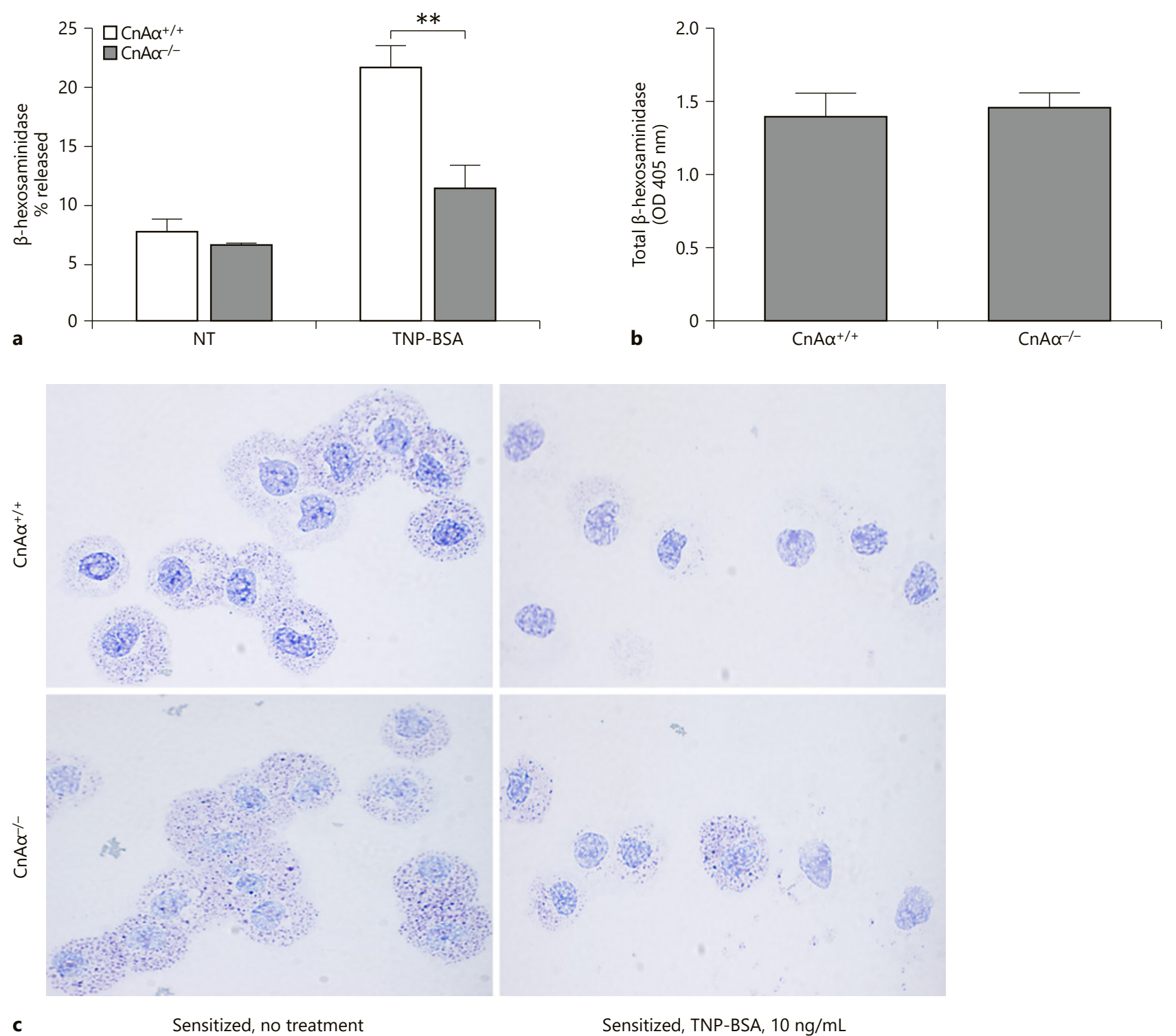

Sensitized, TNP-BSA, $10 \mathrm{ng} / \mathrm{mL}$

Fig. 2. Degranulation is impaired in activated $C n A \alpha^{-/-}$LMCs in vitro. a LMCs from $C n A \alpha^{-1-}$ mice show significantly reduced release of $\beta$-hexosaminidase upon activation compared to WT in vitro. b Total $\beta$-hexosaminidase was similar between both genotypes by calculating amount released and remaining within the LMCs. c Toluidine blue staining was done on LMCs of each geno- type, either sensitized and untreated (left) or sensitized and treated (right) as done when measuring degranulation. Data are expressed as mean \pm SEM ( $n=3$ monocultures of LMCs from each genotype). Student's $t$ test was used for statistical evaluation $-{ }^{* *} p<$ 0.01 . WT, wild-type; LMC, liver-derived mast cells; CnAa, calcineurin subunit A. bers and growth between both strains were similar (data not shown). To assess maturation of cultured LMCs, samples were taken for expression analysis of c-kit (CD117) and indirectly, the FceRI. Analysis by flow cytometry also allows for an objective comparison of the
MC morphology based on forward- and side-scatter properties. The forward- and side-scatter properties of MCs of the 2 strains were similar (Fig. 1c, d, left panels), affirming our toluidine blue staining results. Using FITC-conjugated anti-CD117 antibodies, it was deter- 


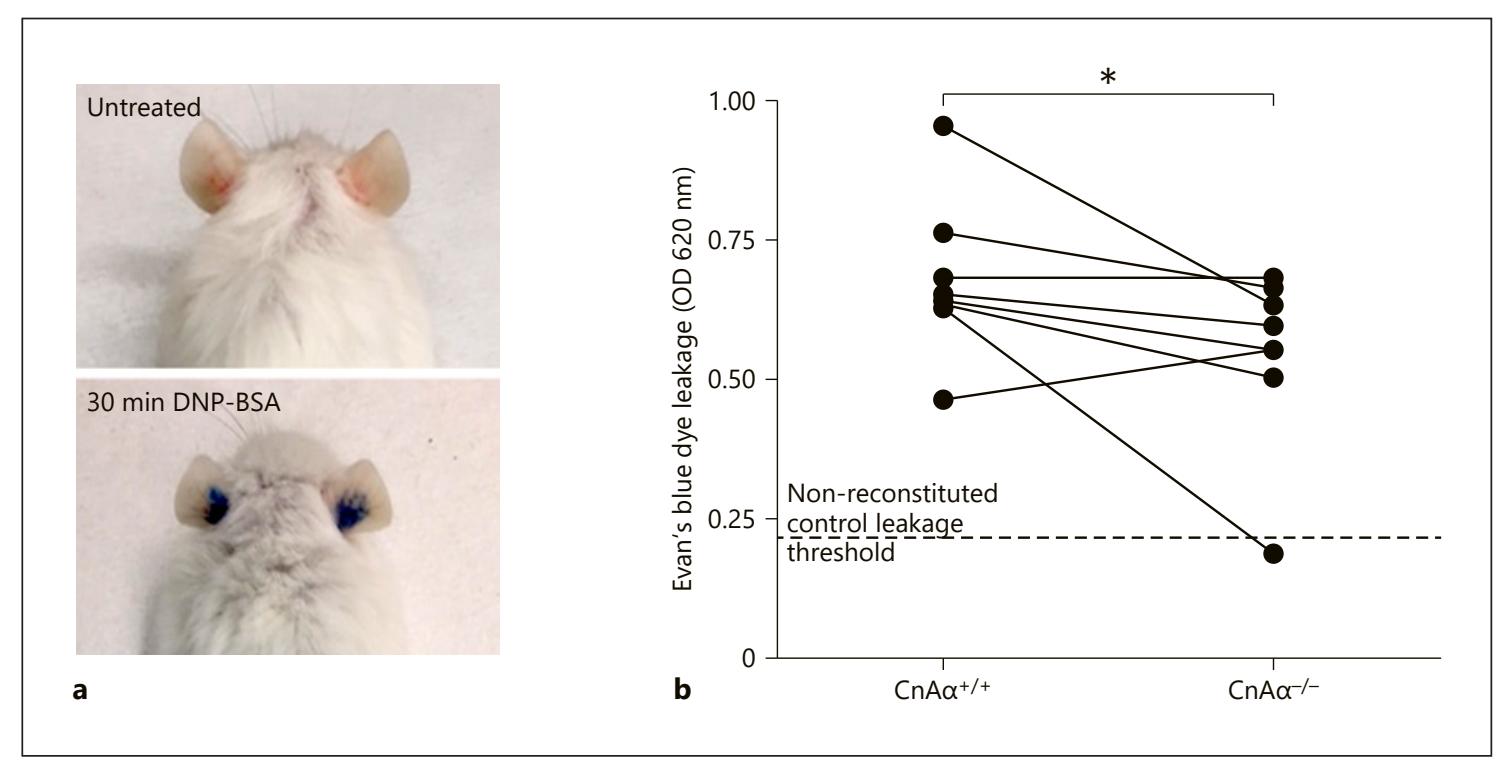

Fig. 3. Degranulation is impaired in tissues with $\mathrm{CnA \alpha ^{-/- }}$ LMCs as measured by Evan's blue dye leakage in vivo. a Mice ears reconstituted with WT LMCs (right ear) displayed higher vascular permeability than ears reconstituted with $\mathrm{CnA \alpha ^{-/- }}$ LMCs (left ear). b Passive cutaneous anaphylaxis reaction experiments in MC-deficient mice ears reconstituted with WT LMCs in the left ears and $\mathrm{CnA \alpha ^{-/- }}$ LMCs in the right ears, showing paired comparison for the same

mined that $\mathrm{CnA} \alpha^{-/-}$MCs had expression levels of c-kit comparable to $\mathrm{CnA \alpha ^{+/+ }} \mathrm{MCs}$ (Fig. 1c, right panels). Similarly, using a FITC anti-IgE antibody to indirectly determine expression of FceRI on IgE-sensitized LMCs, there was comparable expression between $\mathrm{CnA \alpha ^{+/+ }}$ and $\mathrm{CnA} \alpha^{-1-}$ MCs (Fig. 1d, right panels). Furthermore, virtually all gated MCs were positive for both markers in both genotypes of MCs (Fig. 1c, d, middle panels). These results indicate that $\mathrm{CnA \alpha ^{-1- }}$ LMCs are not lacking the receptor for SCF, and additionally, there is no deficiency in the level of FceRI expression. Understandably, using an anti-IgE antibody is an indirect method of measuring FceRI, but it also allows us to form a secondary interpretation - that IgE saturation of the receptors between both genotypes is normal and are similar. Antibodies against FceRI alpha subunits are available but would only give a comparison of surface receptor expression and exclude measurement of IgE binding.

CnA $\alpha$ Gene Deficiency Does Not Impair Calcium Flux upon FceRI-Mediated MC Activation

Calcium signaling precedes and promotes the activation of calcineurin from an inactive to active form and is critical to IgE-dependent signaling cascades. Thus, it is animal. $n=8$ mice (Experiment was conducted 3 separate times with 3,3 , and 2 mice reaching endpoint, respectively. One mouse did not receive a successful tail vein injection on the first attempt in the final repeat and was omitted). Student's paired $t$ test was used for statistical evaluation $-{ }^{*} p<0.05$. WT, wild-type; LMC, liver-derived mast cells; $\mathrm{CnA} \alpha$, calcineurin subunit A; MC, mast cell.

important to assess intracellular calcium fluxes in activated MCs. Sensitized $C n A \alpha^{+/+}$and $C n A \alpha^{-/-}$LMCs were incubated with an intracellular calcium indicator, Fura 2-AM, prior to stimulation. The stimulated intracellular calcium flux was found to be unaffected in $C n A \alpha^{-1-} \mathrm{LMCs}$

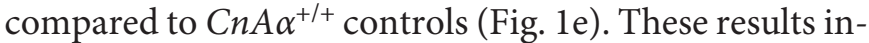
dicate that calcium mobilization is not different between WT and $C n A \alpha^{-/-}$LMCs and signaling leading up to activation of calcineurin is not disrupted.

\section{CnA $\alpha$ Deficiency Impairs FceRI-Mediated MC \\ Degranulation in vitro and in Passive Cutaneous Anaphylaxis in vivo}

To assess the effects of $C n A \alpha$ deficiency on the early phase of FceRI-mediated allergic inflammation, sensitized $\mathrm{CnA} \alpha^{+/+}$and $\mathrm{CnA \alpha ^{-/- }}$ LMCs were stimulated with TNP-BSA for $20 \mathrm{~min}$, and degranulation measured using a $\beta$-hexosaminidase assay. $C n A \alpha^{-/-}$LMCs released approximately $50 \%$ less $\beta$-hexosaminidase than WT cells (Fig. 2a). Total $\beta$-hexosaminidase was determined to assess whether there was a difference that may explain the decreased amount released (Fig. 2b). There was no significant difference between total cell levels of $\beta$-hexosaminidase, indicating that release of preformed 


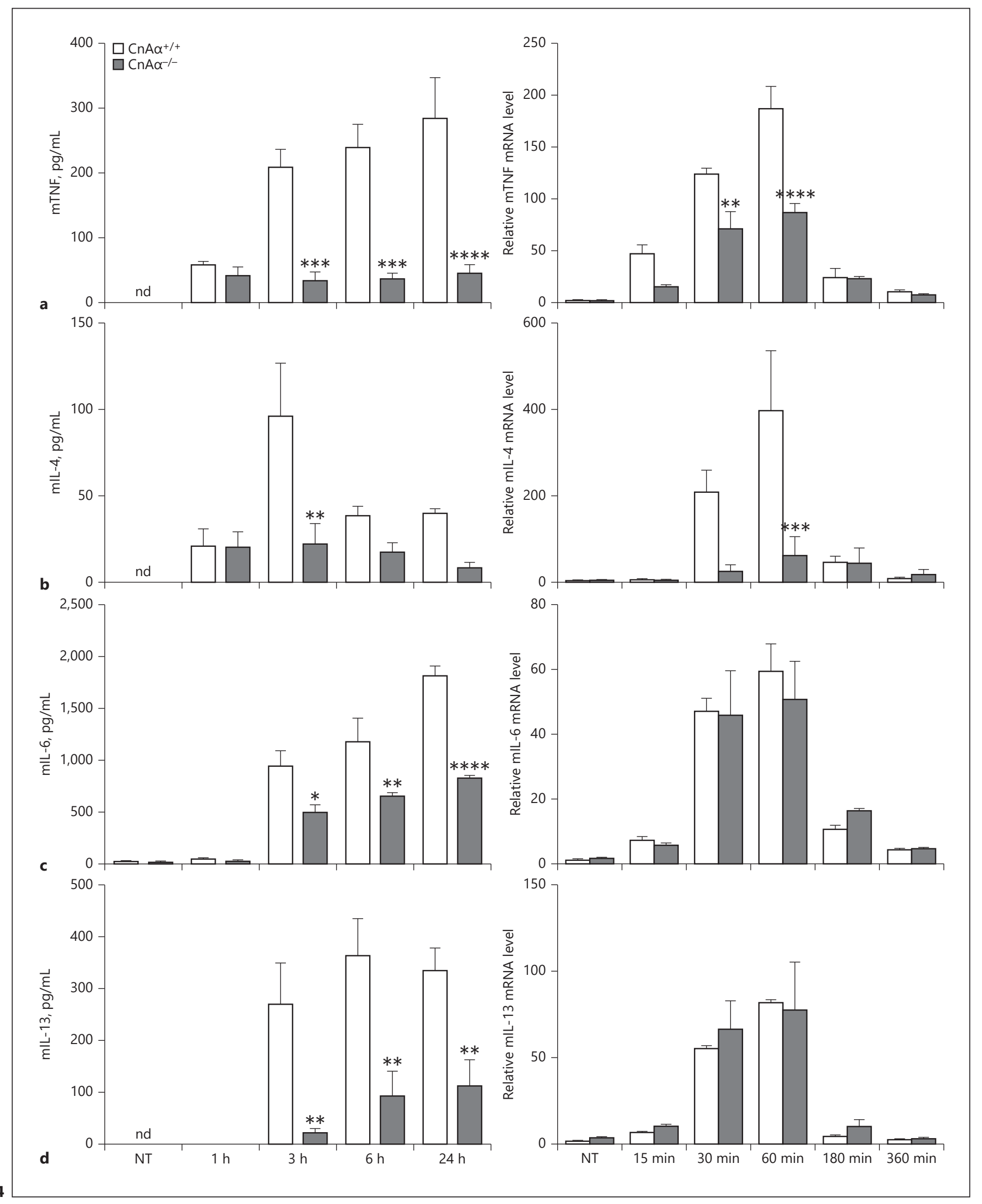

(For legend see next page.) 
$\beta$-hexosaminidase from granules was impaired in $\mathrm{CnA} \alpha^{-/-}$ LMCs. To determine if the CnAa gene is haplosufficient, LMCs heterozygous for the CnAa gene were also assessed for degranulation, and there was no significant difference when compared to $\mathrm{CnA \alpha ^{+/+ }}$ (data not shown). Experiments were not continued using the heterozygous genotype. Toluidine blue staining was also conducted on sensitized untreated and sensitized 20-min TNP-stimulated LMCs of both genotypes, to observe granulation before and after MC activation (Fig. 2c). While $\mathrm{CnA \alpha ^{-/- }}$ LMCs showed the ability to degranulate, at the light-microscopic level, there were fewer degranulated LMCs and contained more granules than $C n A \alpha^{+/+}$LMCs after stimulation, further corroborating our findings that $C n A \alpha$ deficiency resulted in reduced degranulation.

To determine if the in vitro deficiency in degranulation following FceRI-mediated challenge was observable in vivo, a model of passive cutaneous anaphylaxis was used. Considering that $\mathrm{CnA \alpha ^{-/- }}$ mice experience early lethality, in vivo experiments were done on MC-deficient $\mathrm{Kit}^{\mathrm{W} \text {-sh }}$ mice reconstituted with WT or $\mathrm{CnA \alpha ^{-/- }}$ LMC in ear tissues (no issues with histocompatibility). Importantly, by reconstituting MC-deficient mice, the observations and outcomes upon allergen challenge can be considered as MC-specific. In the model of passive cutaneous anaphylaxis, mice were sensitized with antiDNP IgE intradermally in the ear for $24 \mathrm{~h}$ and then challenged with DNP-BSA in 1\% Evan's blue dye through an intravenous injection. Thirty minutes later, ear tissues were collected from the euthanized mice and Evan's blue dye extracted as a measure of vascular permeability. Since the entire ear tissue was harvested, histological assessments were not performed on same specimens. There was more blue dye after stimulation with DNPBSA in the right ears of the mice, for example, reconstituted with $\mathrm{CnA}^{+/+}$LMCs (Fig. 3a, bottom). Examining multiple animals, there was significantly less vascular permeability in the left ear tissues reconstituted with

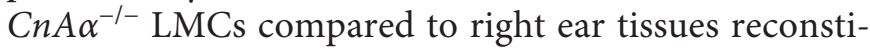

Fig. 4. $C n A \alpha^{-/-}$LMCs have reduced levels of secreted cytokines (left panels) TNF (a), IL-4 (b), IL-6 (c), and IL-13 (d) after activation in comparison with WT LMCs. Gene expression (right) of TNF and IL-4 was specifically reduced in $C n A \alpha^{-/-}$LMCs compared to WT but not IL- 6 and IL-13 mRNA upon FceRI-mediated stimulation. Data are expressed as mean \pm SEM $(n=3$ separate experiments). Two-way ANOVA was used for statistical evaluation $-{ }^{*} p<0.05$. WT, wild-type; LMC, liver-derived mast cells; $\mathrm{CnA} \alpha$, calcineurin subunit A; FceRI, high-affinity receptor for immunoglobulin E; TNF, tumor necrosis factor. tuted with $\mathrm{CnA} \alpha^{+/+}$LMCs in the same mouse (Fig. 3b). These results indicate that there is an impairment in the MC FceRI-mediated early-phase response to allergen associated with $\mathrm{CnAa}$ gene deficiency.

\section{CnA $\alpha^{-/-}$LMCs Have Decreased Amounts of Cytokines} upon FceRI-Mediated Activation in vitro

To assess the impact of CnA $\alpha$ deficiency on the latephase response of FceRI-mediated allergic inflammation, sensitized $\mathrm{CnA} \alpha^{+/+}$and $\mathrm{CnA \alpha ^{-/- }}$ LMCs were stimulated with TNP-BSA for $1,3,6$, or $24 \mathrm{~h}$, and cell supernatants collected for detection of cytokines released by MCs including tumor necrosis factor (TNF), IL-4, IL-6, and IL13. ELISA results for these cytokines showed significantly lower levels of all 4 cytokines in the supernatants at 3 , 6 , and 24 h of TNP-BSA-stimulated $C n A \alpha^{-/-}$LMCs compared to $C n A \alpha^{+/+}$(Fig. 4). Furthermore, there seemed to be an overall blunted level of TNF and IL-4 (Fig. 4a, b), yet a steady increase in cytokine levels with time of stimulation in the $\mathrm{CnA \alpha ^{-/- }}$ LMCs for IL-6 and IL-13 (Fig. 4c, d). These results indicate that $C n A \alpha$ deficiency leads to an impaired cytokine response, specifically TNF, IL-4, IL-6, and IL-13 in FceRI-mediated activation in an in vitro system.

To determine if the reduction in TNF, IL-4, IL-6, and IL-13 levels in the supernatants was a result of decreased gene transcript levels or another mechanism, mRNA levels of the 4 cytokines were analyzed using RT-qPCR. The results showed 2 distinct trends - TNF and IL- 4 transcript levels were significantly diminished in FceRI-mediated

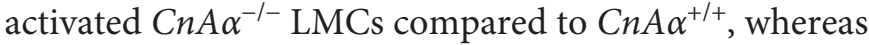
there were no significant differences in IL-6 or IL-13 mRNA levels between both genotypes (Fig. 4c, d). These results suggest that $C n A \alpha$ may differentially regulate expression of genes on a cytokine-specific manner in an FceRI-mediated immune response.

\section{Activation of MAPK Signaling Pathway Family}

Members Is Not Impaired in CnA $\alpha^{-/}$LMCs

The MAPK signaling cascade family members play critical roles in the transcription of various genes including in inflammatory responses, and activation (phosphorylation) of $\mathrm{p} 38$, JNK, and ERK pathways is observed upon FceRI-mediated stimulation. Western blot results of phosphorylated p38, JNK, and ERK proteins showed comparable activation between $\mathrm{CnA} \alpha^{-/-}$and $\mathrm{CnA} \alpha^{+/+}$ LMCs (Fig. 5a). Densitometric analyses further confirmed this as there were no significant differences between the 2 genotypes of LMCs (Fig. 5b). These results indicate that MAPK signaling pathway family members 

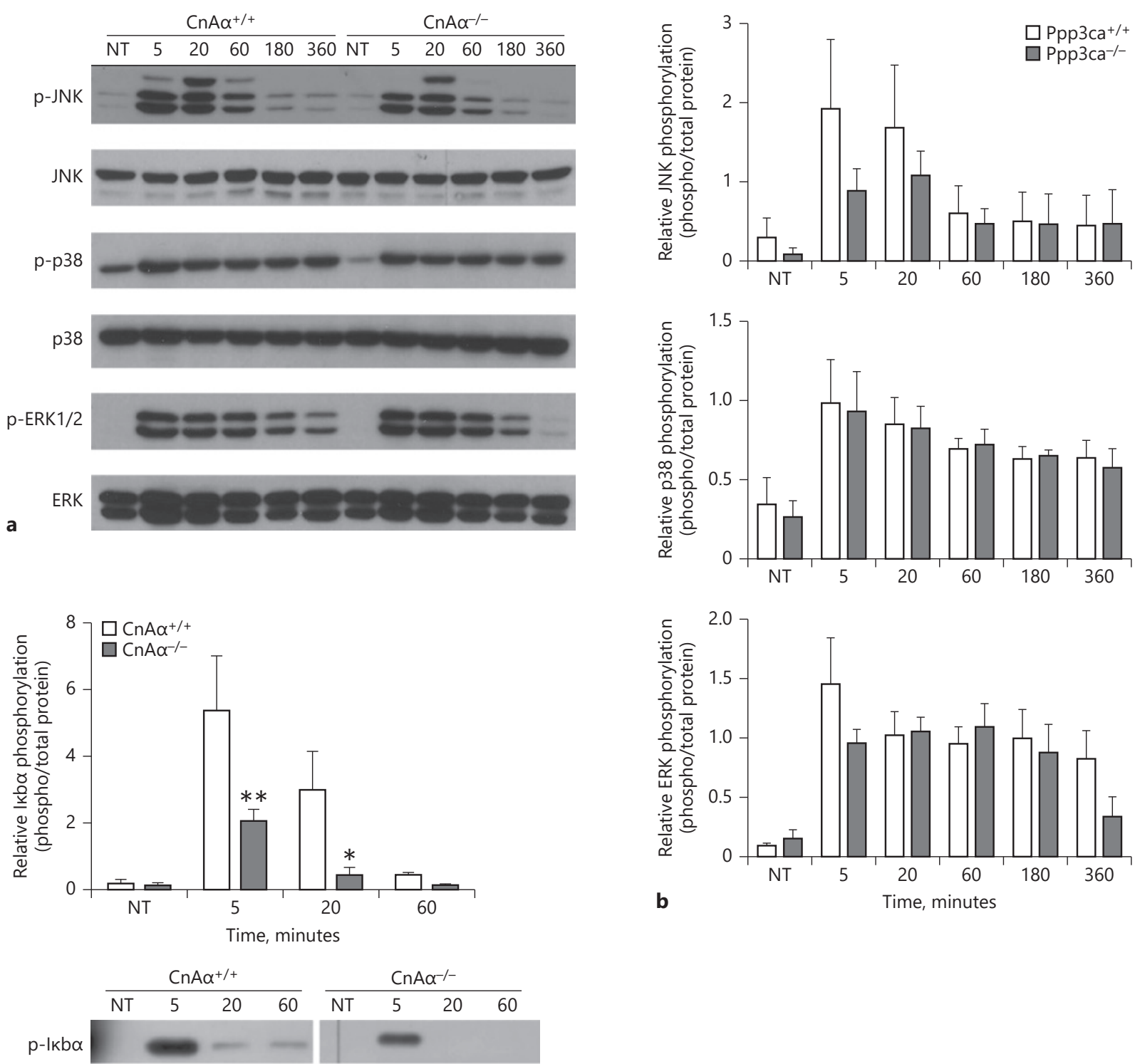

Ikb $\alpha$

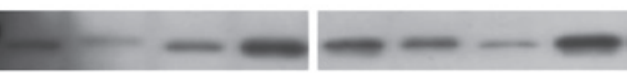

C
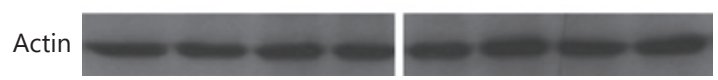

Fig. 5. $C n A \alpha^{-/-}$LMCs have similar MAPK family activation but significantly impaired I $\kappa \mathrm{B} \alpha$ activation compared to WT. JNK, p38, and ERK phosphorylation were analyzed by Western blotting after FceRI-mediated activation (a) and quantified using densitometric analyses (b). c $C n A \alpha^{-l-}$ LMCs have significantly less I $\kappa$ B $\alpha$ phosphorylation at 5 and $20 \mathrm{~min}$ compared to WT counterparts as quantified by densitometric analysis. A representative blot is

shown below the graph. Data are expressed as mean $\pm \operatorname{SEM}(n=3$ separate experiments). Two-way ANOVA was used for statistical evaluation $-{ }^{*} p<0.05$. WT, wild-type; LMC, liver-derived mast cells; $\mathrm{CnA} \alpha$, calcineurin subunit A; FceRI, high-affinity receptor for immunoglobulin E; MAPK, mitogen-activated protein kinase; $\mathrm{I} \kappa \mathrm{B} \alpha$, nuclear factor of kappa light polypeptide gene enhancer in $\mathrm{B}$ cells inhibitor alpha. 


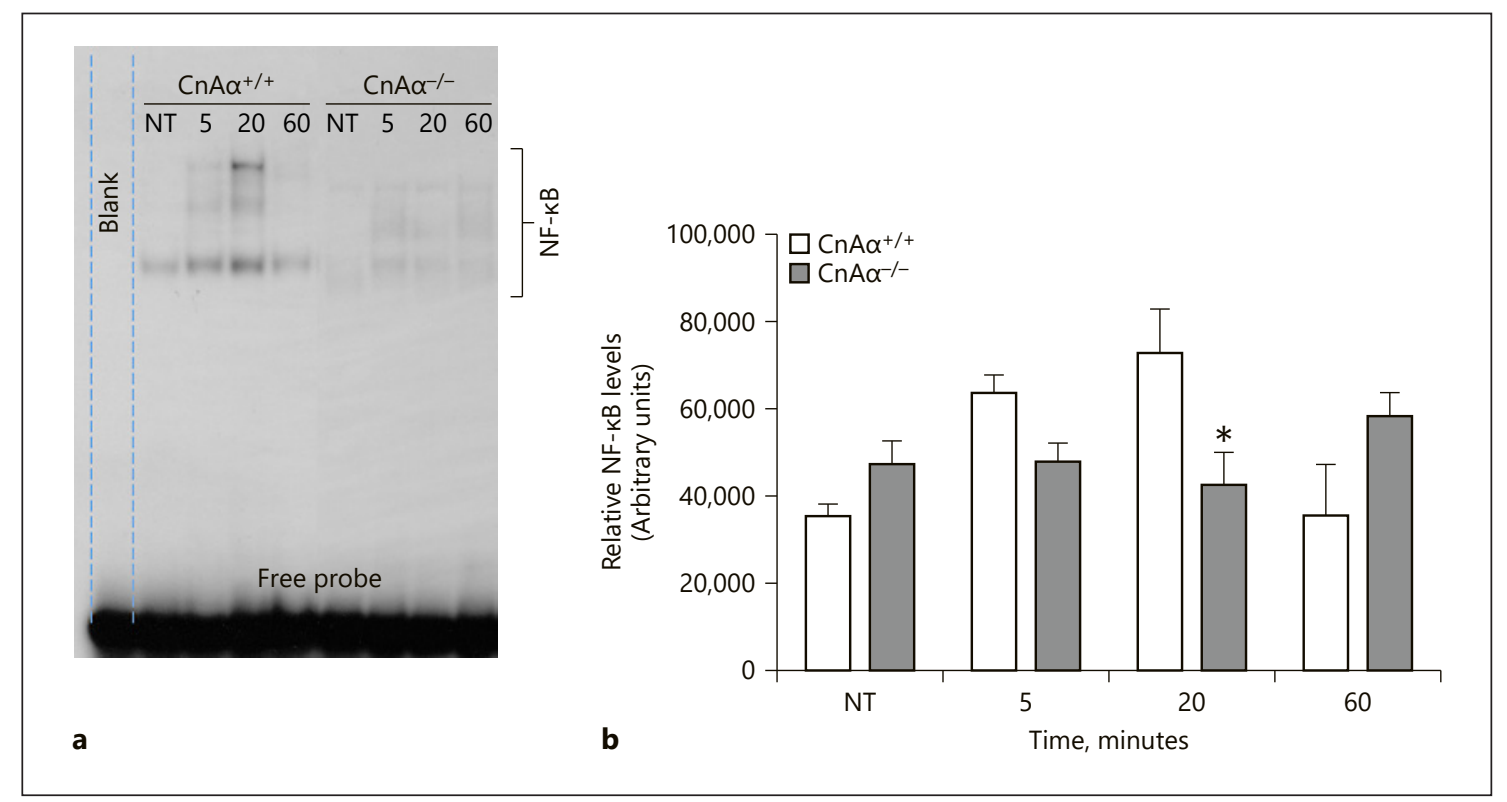

Fig. 6. Nuclear levels of NF- $\kappa \mathrm{B}$ are lower in $C n A \alpha^{-1-} \mathrm{LMCs}$ following FceRI-mediated activation in comparison to WT. Nuclear proteins were isolated and analyzed using EMSA for NF- $\kappa \mathrm{B}$ transcription factor binding at various time points, with significantly less binding $20 \mathrm{~min}$ after stimulation. A representative EMSA blot from 3 independent experiments is shown (a), and blots were quantified using densitometric analysis to assess relative NF- $\kappa B$

function similarly, regardless of the $\mathrm{CnAa}$ gene presence or deficiency. This also raises the notion that these MAPK family members may not play a significant role in regulation of MC degranulation, cytokine synthesis, and release in a $\mathrm{CnA} \alpha$-dependent manner.

\section{Phosphorylation of I $\mathrm{KB} \alpha$ Is Impaired in $\mathrm{CnA} \alpha^{-/-}$ \\ LMCs in an FceRI-Mediated Manner}

Considering NF- $\kappa \mathrm{B}$ signaling is important in the regulation of inflammatory responses and is initiated rapidly upon activation of MCs, the physiological endogenous inhibitor I $\mathrm{B} \alpha$ protein level was measured. Phosphorylation of I $\kappa \mathrm{B} a$ leads to its degradation and liberation of NF$\kappa \mathrm{B}$ which translocates to the nucleus and promotes the transcription of various inflammatory genes. Western blot analysis showed significantly less IкB $\alpha$ phosphorylation in $C n A \alpha^{-/-}$LMCs upon activation in an FceRImediated manner. Specifically, there was significantly impaired phosphorylation of IKB $\alpha$ at 5 and $20 \mathrm{~min}$ after TNP-BSA stimulation in $C n A \alpha^{-/-}$LMCs compared to

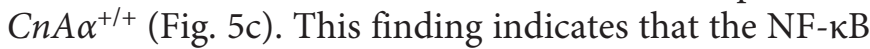
signaling pathway and associated inflammatory elements are impaired by $C n A \alpha$ deficiency. levels (b). Data are expressed as mean \pm SEM ( $n=3$ separate experiments). Two-way ANOVA was used for statistical evaluation - ${ }^{*} p<0.05$. WT, wild-type; LMC, liver-derived mast cells; CnAa, calcineurin subunit A; FceRI, high-affinity receptor for immunoglobulin E; NF- $\kappa \mathrm{B}$, nuclear factor kappa-light-chain-enhancer of activated B cells; EMSA, electromobility shift assay.

\section{Transcription Factor NF- $\kappa B$ Translocation into the}

Nucleus Is Impaired in FceRI-Mediated Activated CnA $\alpha^{-/-}$LMCs

Considering that the inhibitor of NF- $\kappa \mathrm{B}$ I $\kappa \mathrm{B} \alpha$ had impaired phosphorylation and degradation in $\mathrm{CnA \alpha ^{-/- }}$ LMCs, the next step was to confirm that nuclear levels of $\mathrm{NF}-\kappa \mathrm{B}$ were also less in $\mathrm{CnA \alpha ^{-/ }}$ cells. Banding in the electrophoretic mobility shift assay is the result of protein binding to the radiolabelled oligonucleotides containing a NF- $\kappa \mathrm{B}$ binding consensus sequence and thus retarding the probe migration through the gel. When the banding from the blot (Fig. 6a) was quantified using densitometric analysis, there were significantly reduced levels of NF- $\kappa \mathrm{B}$ in the nucleus of $\mathrm{CnA \alpha ^{-/- }}$ LMCs $20 \mathrm{~min}$ after activation with TNP-BSA compared to $C n A \alpha^{+/+}$LMCs (Fig. 6b). This downstream result corresponds with the pattern of phosphorylation and degradation of I $\mathrm{KB} \alpha$ seen in Figure $6 \mathrm{~b}$, where there was significantly increased activation in $\mathrm{CnA} \alpha^{+/+}$LMCs from around $5 \mathrm{~min}$ to $20 \mathrm{~min}$ after MC activation. Furthermore, there is a delayed downward shift in migration of complexes formed between NF- $\kappa B$ proteins and radiolabelled oligonucleotides in the lanes associated with $C n A \alpha^{+/+}$LMCs, indicating that there are 
Fig. 7. Working model of $C n A \alpha$ deficiency and the FceRI-mediated immune response. Activation of mast cells in a system deficient in $C n A \alpha$ resulted in reduced mediators released from preformed granules and reduced overall secretion of de novo synthesized mediators. The latter may be associated with a reduction in NF- $\kappa \mathrm{B}$ signaling pathway activity. $\mathrm{CnAa}$, calcineurin subunit A; FceRI, high-affinity receptor for immunoglobulin E; NF- $\kappa \mathrm{B}$, nuclear factor kappa-light-chain-enhancer of activated $\mathrm{B}$ cells.

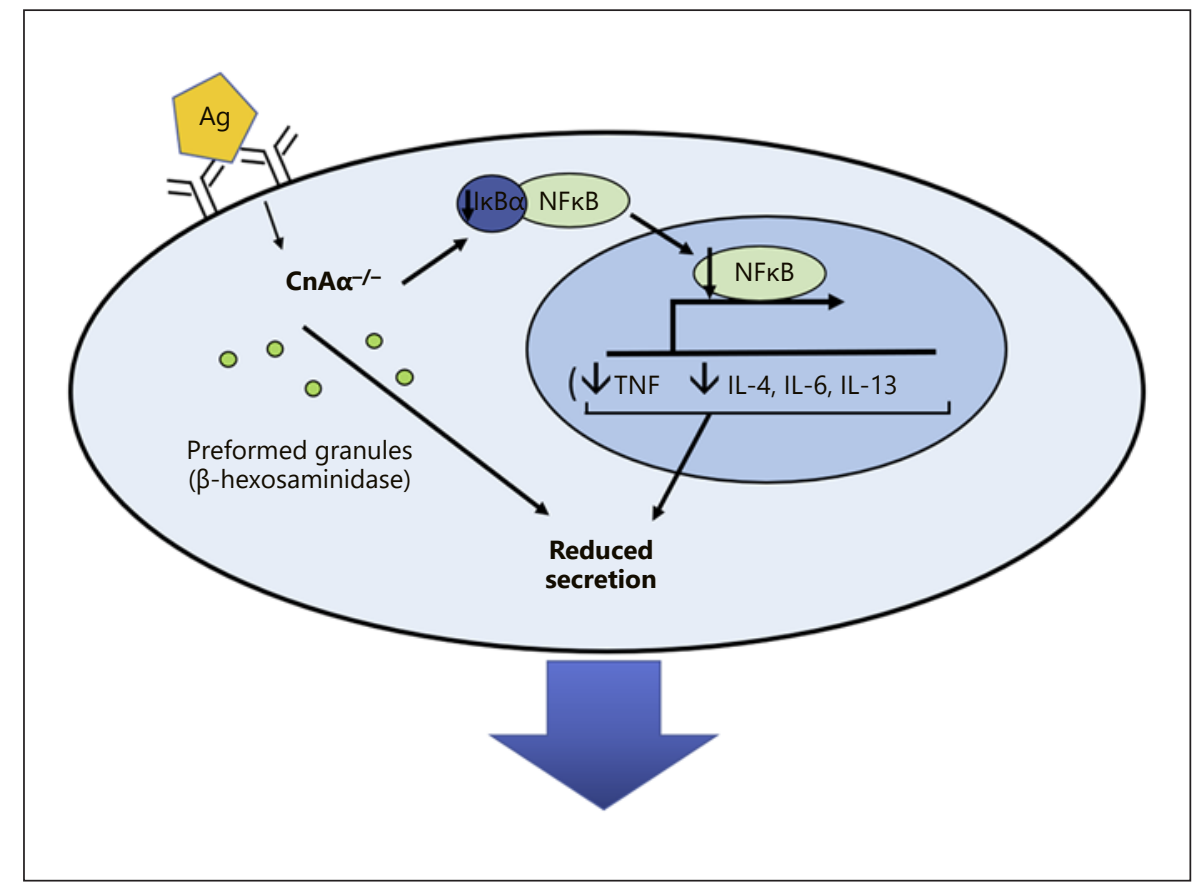

increased NF- $\kappa B$ levels in the nucleus in comparison with $C n A \alpha^{-l-}$ LMCs. Collectively, we demonstrated $C n A \alpha$ deficiency resulted in overall decreased degranulation in the allergic response both in vitro and in vivo and decreased secretion of newly synthesized cytokines in vitro, which is likely mediated by impaired NF- $\kappa B$ signaling (Fig. 7).

\section{Discussion}

Various types of leukocytes are responsible for the defense of our bodies, requiring these cells to detect and interpret signals from the environment and react in a preprogrammed manner, presumably with an appropriate response. Calcineurin is an important molecule in the flow from interpretation to response. Because of this pivotal role, calcineurin also potentially contributes to undesirable responses leading to harmful consequences. Various calcineurin inhibitors have been used based on antiinflammatory effects observed in clinical settings, including allergy. Ubiquitous in mammalian tissues and with an evolutionarily conserved catalytic domain, isoforms of calcineurin are likely to have critical functions in cells $[26,27]$. Certain isoforms may regulate tissue-specific functions such as development and homeostasis. Our experiments identified a role for the alpha isoform in the context of MC allergy and provide further research directions to expand the limited literature on the contributions of $C n A \alpha$ to disease.

$\mathrm{CnAa}$ gene deficiency in mice resulted in changes in maturation in the kidney and epidermal cells but not Tand $\mathrm{B}$-cell growth and development, indicating there are isoform-specific contributions in certain cell types. In

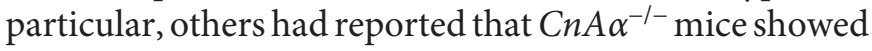
a decrease in vesicle number and protein content of the submandibular glands [23]. Thus, our first assessment was to determine whether $\mathrm{CnA} \alpha$ gene deficiency has any effect on structural and granular properties of the MCs. Cultured MCs displayed similar morphology (size and structure, observed microscopically) between both genotypes, and this was confirmed by similar forward-scatter profiles from flow cytometric analysis. Additionally, there was no significant difference found in granules of the MCs, at least measured by $\beta$-hexosaminidase content. While MC granules contain multiple factors such as histamine and $\beta$-hexosaminidase, both are typically released together from granules [28], and while both are suitable for determining degranulation, the latter is a popular method for assessment [29]. Development and expression of surface receptors c-Kit and FceRI were also similar between both genotypes. The sum of our findings indicates there is no apparent consequence of $\mathrm{CnAa}$ gene deficiency on MC development and maturation, at least among the parameters we measured. 
Calcium signaling is integral to FceRI-mediated signaling and in fact precedes activation of calcineurin, thus it was important to assess intracellular $\mathrm{Ca}^{2+}$ flux in both genotypes. Peak intracellular $\mathrm{Ca}^{2+}$ levels were previously associated with maximal histamine release in a MC line [30], and an absence of sufficient $\mathrm{Ca}^{2+}$ in the cytosol resulted in halting gene transcription as well as rapid shuttling of transcription factors back into the cytoplasm to an inactive state [31]. Finding no difference in the pattern and magnitude of the $\mathrm{Ca}^{2+}$ flux, we proceeded to measure functional outcomes following FceRI activation.

Despite the MCs of the 2 genotypes possessing similar total amounts of $\beta$-hexosaminidase, degranulation of preformed mediators was reduced in $\mathrm{CnA \alpha ^{-1- }}$ MCs com-

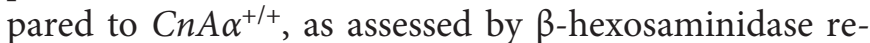
lease in vitro. This difference in degranulation was detectable in the passive cutaneous anaphylactic reaction in mouse ear tissues in the reconstitution experiment. The reduction in the in vivo permeability can be attributed to decreased release of mediators such as histamine from granules as histamine readily promotes vascular permeability [32]. Previously, calcineurin inhibitors were shown to inhibit release of histamine from granules upon activation of MCs in an IgE-dependent manner [33], and now, we build on that finding by showing $\mathrm{CnA \alpha}$ is critical to the release of preformed mediators, including by assessing permeability changes driven by these immediate mediators in vivo. Activation of the FceRI-mediated signaling pathway leads to the activation of a complex of proteins involving Carma1-Bcl10-Malt1 by calcineurin, which may be responsible for downstream signaling through inhibitor of nuclear factor kappa-B kinase 2 $(\mathrm{IKK}-\beta)[34,35]$. IKK- $\beta$ has been identified as a critical signaling component in the pathway leading to degranulation as a deficiency resulted in impaired FceRI-mediated degranulation of MCs [36]. IKK- $\beta$ phosphorylates synaptosomal-associated protein 23 , which is involved in MC exocytotic mechanisms [36, 37]. Of importance, this mechanism of degranulation is independent of NF- $\mathrm{kB}$ activation, which is further corroborated by findings that toll-like receptor signaling (which activates NF- $\mathrm{B}$ ) did not induce degranulation in MCs [38]. Although the exact mechanism has not been established, our results demonstrate a significant contribution of $C n A \alpha$ in FceRImediated MC degranulation.

In addition to release of preformed mediators, MCs respond to stimulation through FceRI with de novo synthesis and secretion of cytokines. Analysis of the secreted mediator levels between stimulated MCs of both genotypes showed cytokine-specific impacts of $C n A \alpha$. While protein levels of all cytokines examined - TNF, IL-4, IL-6, and IL13 - were significantly lower in $\mathrm{CnA \alpha ^{-/- }}$ than in $\mathrm{CnA} \alpha^{+/+}$ MC supernatants following activation, there were 2 distinct trends in transcript levels of the cytokines. TNF and IL-4 showed parallel low mRNA levels; however, IL-6 and IL-13 gene transcript levels were similar between both genotypes throughout the duration of activation. This may suggest that decreases in IL- 6 and IL- 13 protein were not due to reduced gene transcription but perhaps other mechanisms dependent on $C n A \alpha$, such as through interactions with transcription factors or through regulation of secretory pathway mechanisms. For example, in human skeletal muscle cells, calcineurin was found to regulate TNF and IL- 6 gene expression differentially, and the addition of calcineurin inhibitors decreased ionomycin-induced IL-6 but not TNF mRNA levels [39]. Possible mechanisms of selective posttranscriptional regulation of these genes also involve mRNA stabilization and translation; however, there is work to be done to identify if there is a role for $\mathrm{CnA} \alpha$ in these processes. There may be regulation at the level of mediator release by the soluble NSF attachment protein family as different members have roles in packaging, intracellular trafficking, and extracellular secretion of cytokines and chemokines [40]. A precedent has been published showing calcineurin is crucial in exocytotic processes through interactions with soluble NSF attachment family members [41, 42], with the latter implicated in release of mediators by activated MCs.

MAPK family members p38 kinase, JNK, and ERK1/2 are known to contribute to FceRI-mediated MC activation, and Western blots and respective densitometric analyses showed similarities between the 2 genotypes. This result is comparable to our report using ${\text { Rcan } 1^{-/}}^{-}$ MCs, which exhibited similar phosphorylation of $\mathrm{p} 38$, JNK, and ERK1/2 to wild-type levels [16].

The NF- $\kappa \mathrm{B}$ signaling pathway is crucial in the transcription of many pro-inflammatory mediators in multiple diseases [43] including allergic inflammation. Our results showed reduced NF- $\mathrm{KB}$ in $\mathrm{CnA \alpha ^{-/- }}$ MCs in compar-

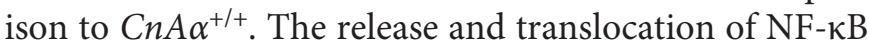
into the nucleus to drive gene transcription are impaired and may be responsible for the observed phenotypes in $\mathrm{CnA \alpha ^{-l- }}$ MCs. This outcome again corroborates our study of regulator of calcineurin 1 deficiency, in which loss of the calcineurin inhibitor resulted in significantly greater $\mathrm{NF}-\kappa \mathrm{B}$ activity and higher gene transcription [16]. Additionally, pharmaceutical calcineurin inhibitors have been shown to reduce NF- $\kappa B$ activity [44]. Activation of the $\mathrm{NF}-\kappa \mathrm{B}$ signaling axis from calcineurin is possibly through the upstream Carma1-Bcl10-Malt1 complex formation, 
which is also important in T-cell receptor activation [45]. This was corroborated by other research finding a role for calcineurin in transient dephosphorylation of Bcl-10 to be necessary for NF- $\kappa B$ activation in $\mathrm{T}_{\mathrm{H}}$ cells [34].

Considering none of our measures were absolutely abolished, there was residual calcineurin activity, likely due to the $\beta$ isoform, so determining the role of this isoform remains to be done. The $\beta$ isoform has been regarded as the predominant isoform in lymphocytes and plays a critical role in immune settings [10]. Meanwhile, it is evident that $C n A \alpha$ definitively and $C n A \beta$ likely contribute to the FceRI-mediated immune response.

\section{Acknowledgments}

This manuscript is a tribute to honor the mentorship and contributions to immunology by Dr. Tong-Jun Lin (1963-2018). We would also like to thank Fang Liu for her excellent technical support.

\section{Statement of Ethics}

Protocols (18-003 and 18-004) were approved by the University Committee on Laboratory Animals, Dalhousie University, Canada, in accordance with the guidelines of the Canadian Council of Animal Care.

\section{Conflict of Interest Statement}

The authors declare no conflicts of interest.

\section{Funding Sources}

This research project was funded by a grant from the Canadian Institutes of Health Research (MOP-68815) to T.-J.L.

\section{Author Contributions}

E.L. contributed to conceptualization, generation, and formal analysis of experimental data for this manuscript. Z.P. provided guidance and assistance with experimental assays. A.W.S. and T.J.L. provided concept design, guidance, and supervision for this research project. E.L. and A.W.S. prepared and edited the manuscript. Address all correspondences to Dr. Andrew W. Stadnyk at astadnyk@dal.ca.

\section{Data Availability Statement}

All data generated or analyzed during this study are included in this article. Further inquiries can be directed to the corresponding author.

\section{References}

1 da Silva EZ, Jamur MC, Oliver C. Mast cell function: a new vision of an old cell. J Histochem Cytochem. 2014;62(10):698-738.

2 Broide DH. Molecular and cellular mechanisms of allergic disease. J Allergy Clin Immunol. 2001;108(2 Suppl):S65-71.

3 Bischoff SC. Role of mast cells in allergic and non-allergic immune responses: comparison of human and murine data. Nat Rev Immunol. 2007;7(2):93-104.

4 Moon TC, Befus AD, Kulka M. Mast cell mediators: their differential release and the secretory pathways involved. Front Immunol. 2014;5(569):569-18.

5 Moon TC, St Laurent CD, Morris KE, Marcet C, Yoshimura T, Sekar Y, et al. Advances in mast cell biology: new understanding of heterogeneity and function. Mucosal Immunol. 2010;3(2):111-28.

6 Gilfillan AM, Tkaczyk C. Integrated signalling pathways for mast-cell activation. Nat Rev Immunol. 2006;6(3):218-30.

7 Turner H, Kinet JP. Signalling through the high-affinity IgE receptor Fc epsilonRI. Nature. 1999;402(6760 Suppl):B24-30.
8 Roth K, Chen WM, Lin TJ. Positive and negative regulatory mechanisms in high-affinity IgE receptor-mediated mast cell activation. Arch Immunol Ther Exp. 2008;56(6):385-99.

9 Aramburu J, Heitman J, Crabtree GR. Calcineurin: a central controller of signalling in eukaryotes. EMBO Rep. 2004;5(4):343-8.

10 Williams CR, Gooch JL. Calcineurin inhibitors and immunosuppression - a tale of two isoforms. Expert Rev Mol Med. 2012;14:e14.

11 Rumi-Masante J, Rusinga FI, Lester TE, Dunlap TB, Williams TD, Dunker AK, et al. Structural basis for activation of calcineurin by calmodulin. J Mol Biol. 2012;415(2):307-17.

12 Rusnak F, Mertz P. Calcineurin: form and function. Physiol Rev. 2000;80(4):1483-521.

13 Ye Q, Feng Y, Yin Y, Faucher F, Currie MA, Rahman MN, et al. Structural basis of calcineurin activation by calmodulin. Cell Signal. 2013 Dec 1;25(12):2661-7.

14 Li H, Rao A, Hogan PG. Interaction of calcineurin with substrates and targeting proteins. Trends Cell Biol. 2011;21(2):91-103.

15 Crabtree GR. Calcium, calcineurin, and the control of transcription. J Biol Chem. 2001; 276(4):2313-6.
16 Yang YJ, Chen W, Edgar A, Li B, Molkentin JD, Berman JN, et al. Rcan1 negatively regulates Fc epsilonRI-mediated signaling and mast cell function. J Exp Med. 2009;206(1): 195-207.

17 Ho S, Clipstone N, Timmermann L, Northrop J, Graef I, Fiorentino D, et al. The mechanism of action of Cyclosporin A and FK506. Clin Immunol Immunopathol. 1996;80(3):S40-5.

18 Hoorn EJ, Walsh SB, McCormick JA, Zietse R, Unwin RJ, Ellison DH. Pathogenesis of calcineurin inhibitor-induced hypertension. J Nephrol. 2012;25(3):269-75.

19 Naesens M, Kuypers DR, Sarwal M. Calcineurin inhibitor nephrotoxicity. Clin J Am Soc Nephrol. 2009;4(2):481-508.

20 Segal AO, Ellis AK, Kim HL. CSACI position statement: safety of topical calcineurin inhibitors in the management of atopic dermatitis in children and adults. Allergy Asthma Clin Immunol. 2013;9(1):24.

21 Castro AP. Calcineurin inhibitors in the treatment of allergic dermatitis. J Pediatr. 2006; 82(5 Suppl):S166-72. 
22 de Paulis A, Cirillo R, Ciccarelli A, de Crescenzo G, Oriente A, Marone G. Characterization of the anti-inflammatory effect of FK-506 on human mast cells. J Immunol. 1991; 147(12):4278-85.

23 Reddy RN, Pena JA, Roberts BR, Williams SR, Price SR, Gooch JL. Rescue of calcineurin $\mathrm{Aa}(-/-)$ mice reveals a novel role for the $\alpha$ isoform in the salivary gland. Am J Pathol. 2011; 178(4):1605-13.

24 Zhang BW, Zimmer G, Chen J, Ladd D, Li E, Alt FW, et al. T cell responses in calcineurin A alpha-deficient mice. J Exp Med. 1996; 183(2):413-20.

25 MacNeil AJ, Yang YJ, Lin TJ. MAPK kinase 3 specifically regulates $\mathrm{Fc}$ epsilonRI-mediated IL-4 production by mast cells. J Immunol. 2011;187(6):3374-82.

26 Aramburu J, Heitman J, Crabtree GR. Calcineurin: a central controller of signalling in eukaryotes. EMBO Rep. 2004;5(4):343-8.

27 Gooch JL. An emerging role for calcineurin Aalpha in the development and function of the kidney. Am J Physiol Renal Physiol. 2006; 290(4):F769-76.

28 Moon TC, Befus AD, Kulka M. Mast cell mediators: their differential release and the secretory pathways involved. Front Immunol. 2014;5(569):569-18.

29 Kuehn HS, Radinger M, Gilfillan AM. Measuring mast cell mediator release. Curr Protoc Immunol. 2010; Chapter 7:Unit7.38.

30 Beaven MA, Rogers J, Moore JP, Hesketh TR, Smith GA, Metcalfe JC. The mechanism of the calcium signal and correlation with histamine release in $2 \mathrm{H} 3$ cells. J Biol Chem. 1984; 259(11):7129-36
31 Timmerman LA, Clipstone NA, Ho SN, Northrop JP, Crabtree GR. Rapid shuttling of NF-AT in discrimination of Ca2+ signals and immunosuppression. Nature. 1996; 383(6603):837-40.

32 Ashina K, Tsubosaka Y, Nakamura T, Omori $\mathrm{K}$, Kobayashi K, Hori M, et al. Histamine induces vascular hyperpermeability by increasing blood flow and endothelial barrier disruption in vivo. PLoS One. 2015;10(7):e0132367.

33 Harrison CA, Bastan R, Peirce MJ, Munday MR, Peachell PT. Role of calcineurin in the regulation of human lung mast cell and basophil function by cyclosporine and FK506. Br J Pharmacol. 2007;150(4):509-18.

34 Frischbutter S, Gabriel C, Bendfeldt H, Radbruch A, Baumgrass R. Dephosphorylation of $\mathrm{Bcl}-10$ by calcineurin is essential for canonical NF- $\kappa B$ activation in Th cells. Eur J Immunol. 2011;41(8):2349-57.

35 Klemm S, Ruland J. Inflammatory signal transduction from the Fc epsilon RI to NFkappa B. Immunobiology. 2006;211(10):81520.

36 Suzuki K, Verma IM. Phosphorylation of SNAP-23 by IkappaB kinase 2 regulates mast cell degranulation. Cell. 2008;134(3):485-95.

37 Guo Z, Turner C, Castle D. Relocation of the t-SNARE SNAP-23 from lamellipodia-like cell surface projections regulates compound exocytosis in mast cells. Cell. 1998;94(4):53748.

38 Klemm S, Gutermuth J, Hültner L, Sparwasser T, Behrendt H, Peschel C, et al. The Bcl10 Malt1 complex segregates Fc epsilon RI-mediated nuclear factor kappa B activation and cytokine production from mast cell degranulation. J Exp Med. 2006;203(2):337-47.
39 Keller C, Hellsten Y, Steensberg A, Pedersen BK. Differential regulation of IL-6 and TNFalpha via calcineurin in human skeletal muscle cells. Cytokine. 2006;36(3-4):141-7.

40 Lorentz A, Baumann A, Vitte J, Blank U. The SNARE machinery in mast cell secretion. Front Immunol. 2012 Jun;3:143.

41 McGrath K, Agarwal S, Tonelli M, Dergai M, Gaeta AL, Shum AK, et al. A conformational switch driven by phosphorylation regulates the activity of the evolutionarily conserved SNARE Ykt6. Proc Natl Acad Sci USA. 2021; 118(12):1-12.

42 Bennett JC, Roggero CM, Mancifesta FE, Mayorga LS. Calcineurin-mediated dephosphorylation of synaptotagmin VI is necessary for acrosomal exocytosis. J Biol Chem. 2010; 285(34):26269-78.

43 Christian F, Smith EL, Carmody RJ. The regulation of NF- $\kappa B$ subunits by phosphorylation. Cells. 2016;5(1):1-12.

44 Frantz B, Nordby EC, Bren G, Steffan N, Paya $\mathrm{CV}$, Kincaid RL, et al. Calcineurin acts in synergy with PMA to inactivate I kappa B/MAD3, an inhibitor of NF-kappa B. EMBO J. 1994; 13(4):861-70.

45 Palkowitsch L, Marienfeld U, Brunner C, Eitelhuber A, Krappmann D, Marienfeld RB. The Ca2+-dependent phosphatase calcineurin controls the formation of the Carma1Bcl10-Malt1 complex during T cell receptorinduced NF-kappaB activation. J Biol Chem. 2011;286(9):7522-34. 